\title{
DETEKSI DINI PENCAPAIAN PERKEMBANGAN ANAK USIA 2-3 TAHUN BERDASARKAN STANDAR NASIONAL PENDIDIKAN ANAK USIA DINI
}

\author{
Eka Damayanti \\ Jurusan Pendidikan Islam Anak Usia Dini \\ Fakultas Tarbiyah dan Keguruan, UIN Alauddin Makassar \\ E-mail: eka.damayanti@uin-alauddin.ac.id \\ Nurhasanah \\ Jurusan Pendidikan Islam Anak Usia Dini \\ Fakultas Tarbiyah dan Keguruan, UIN Alauddin Makassar \\ E-mail: nurhasanahsultan077@gmail.com \\ Nurafia \\ Jurusan Pendidikan Islam Anak Usia Dini \\ Fakultas Tarbiyah dan Keguruan, UIN Alauddin Makassar \\ E-mail: nurafia419@gmail.com \\ Elim Emelia Kamal \\ Jurusan Pendidikan Islam Anak Usia Dini \\ Fakultas Tarbiyah dan Keguruan, UIN Alauddin Makassar \\ E-mail: elimamelia@gmail.com
}

\begin{abstract}
Abstrak
Penelitian ini bertujuan untuk mengetahui gambaran tingkat pencapaian perkembangan anak usia 2-3 tahun berdasarkan standar pendidikan nasional PAUD dan melakukan deteksi dini terhadap hambatan pencapaian perkembangannya. Penelitian ini merupakan penelitian kualitiatif jenis deskriptif dengan subjek penelitian sebanyak tiga anak. Data dikumpulkan menggunakan observasi dan wawancara serta memberikan beberapa rangkaian stimulus untuk mendukung munculnya respon pencapaian perkembangan yang hendak diukur. Data dianalisis menggunakan analisis deskriptif. Hasil penelitian menunjukkan bahwa ketiga subjek telah memenuhi hampir semua indikator tingkat pencapaian perkembangan berdasarkan tingkat pencapaian perkembangan anak dalam Peraturan Menteri Pendidikan dan Kebudayaan Republik Indonesia Nomor 137 Tahun 2014 Tentang Standar Nasional Pendidikan Anak Usia Dini, meskipun masih ada beberapa yang belum mampu dilakukan. Berhasil tidaknya perkembangan dari ketiga subjek tidak terlepas dari peran orang tua dalam memberikan stimulus dan bimbingan yang tepat menentukan keberhasilan pencapaian perkembangan anak dari semua aspek perkembangan yang diukur: aspek nilai agama-moral, fisik-motorik, kognitif, bahasa, sosial-emosional, dan seni.
\end{abstract}

Kata Kunci: Anak Usia Dini, Deteksi Dini, Pencapaian Perkembangan 


\begin{abstract}
This study aimed at describing the level of the developmental achievement of 2-3 years old children based on PAUD national education standards and early detection of barriers to achieving development. This research is a descriptive qualitative research with three research subjects. The data was collected using observations, interviews, and a series of stimuli to support the emergence of responses to developmental achievements to be measured, namely aspects of religious-moral, physical-motoric, cognitive, linguistic, social-emotional, and artistic. The collected data was analyzed using descriptive analysis. The results showed that the three subjects had reached almost all indicators of the developmental achievement level based on the child developmental achievement level in the Republic of Indonesia Minister of Education and Culture Regulation No. 137 of 2014 concerning the National Standards for Early Childhood Education, although there were still some that had not been able to do. The success or failure of the development of the three subjects cannot be separated from the role of parents in providing appropriate stimulus and guidance to children. For 2-3 years' children, exemplary and stimuli from parents greatly determine the success of achieving child development from all aspects of development that are measured: aspects of religious-moral, physicalmotoric, cognitive, linguistic, social-emotional, and artistic.
\end{abstract}

Keywords: Early Detection, Early Childhood, Developmental Achievement

\title{
PENDAHULUAN
}

Setiap manusia melalui tahapan perkembangan yang berbeda-beda berdasarkan usia yang dijalani mulai dari fase bayi, kanak-kanak awal-kanak-kanak akhir, remaja, dewasa awal, dewasa akhir dan lanjut usia. Hurlock (2002) mengungkapkan perkembangan merupakan serangkaian perubahan yang progresif yang terjadi akibat dari proses kematangan dan pengalaman. Perkembangan bukan hanya terbatas pada pengertian pertumbuhan yang semakin membesar, namun menurut Desmita (2012) di dalam perkembangan terkandung serangkaian perubahan yang berlangsung secara terus-menerus dan bersifat tetap dari fungsi-fungsi jasmaniah dan rohaniah yang memiliki individu menuju ke tahap kematangan melalui pertumbuhan, pemasakan, dan belajar.

Istilah anak usia dini merujuk pada anak yang berusia 0-6 tahun (UU Sistem Pendidikan Nasional No 20 Tahun 2003 pasal 1 ayat 14). Anak-anak usia dini berada pada masa keemasan (golden age). Menurut Sit (2017) masa ini disebut masa keemasan sebab pada usia dini terjadi perkembangan yang sangat menakjubkan dan terbaik pada usia dini. Perkembangan anak usia dini mencakup berbagai aspek yaitu perkembangan fisik, sosial, emosi dan kognitif. Danim (2010) perkembangan pada anak usia merupakan sebuah perubahan secara bertahap dalam kemampuan, emosi, dan keterampilan yang terus berlangsung hingga mencapai usia tertentu. Santrock (2007) menyatakan perkembangan anak usia dini mencakup 
perkembangan fisik, kognitif, sosial emosional, konteks social, moral, bahasa, identitas diri, dan gender.

Banyaknya aspek perkembangan yang diungkapkan dari berbagai ahli, akhirnya di dalam Peraturan Menteri Pendidikan dan Kebudayaan Nomor 146 Tahun 2014 tentang Kurikulum 2013 Pendidikan Anak Usia Dini pada pasal 5 dinyatakan, bahwa aspek-aspek perkembangan dalam kurikulum Pendidikan Anak Usia Dini mencakup nilai agama, nilai moral, fisik-motorik, kognitif, bahasa, sosial-emosional, dan seni. Ketujuh aspek perkembangan itu menjadi penting untuk diperhatikan dari orang tua dan para pendidik.

Perkembangan pada anak usia dini memiliki tingkat pencapaian yang berbedabeda sesuai usia anak itu sendiri. Begitu pula bagi anak yang berusia 2-3 tahun memiliki perbedaan standar tingkat pencapaian perkembangan dibanding usia di bawah atau di atasnya. Tingkat pencapaian perkembangan itu secara rinci telah tertuang dalam Peraturan Menteri Pendidikan dan Kebudayaan Republik Indonesia Nomor 137 Tahun 2014 Tentang Standar Nasional Pendidikan Anak Usia Dini. Dalam peraturan itu berisi tentang Tingkat Pencapaian Perkembangan Anak mulai aspek perkembangan nilai agama-moral, fisik-motorik, kognitif, bahasa, sosial-emosional, dan seni.

Tingkat pencapaian disetiap aspek perkembangan anak sangat penting. Hal itu disebabkan karena dengan melihat indikator-indikator tingkat pencapaian anak, orang tua atau pendidik mampu mengetahui dan mendeteksi adanya penyimpangan perkembangan yang membuat aspek perkembangan itu tidak berkembangan secara normal. Oleh karena itu, bisa dilakukan antisipasi atau pencegahan dini penyimpangan perkembangan pada anak. Menurut Kementerian Kesehatan RI (2013) deteksi dini tumbuh kembang anak adalah kegiatan/pemeriksaan untuk menemukan secara dini adanya penyimpangan tumbuh kembang pada balita dan anak prasekolah. Dengan ditemukan secara dni penyimpangan/ masalah tumbuh kembang anak, maka intervensi akan lebih mudah dilakukan. Namun apabila penyimpangan terlambat diketahui, maka intervensinya akan lebih sulit dan hal ini akan berpengaruh pada tumbuh kembang anak.

Oleh karena itu, maka peneliti mengangkat judul penelitian Deteksi Dini Pencapaian Perkembangan Anak Usia 2-3 Tahun Berdasarkan Standar Nasional Pendidikan Anak Usia Dini dengan harapan mampu memberikan gambaran mengenai karakteristik perkembangan anak, stimulasi yang perlu orangtua berikan kepada anak agar setiap aspek perkembangan berkembang secara optimal.

\section{METODE PENELITIAN}

Penelitian ini merupakan penelitian kualitiatif jenis deskriptif dengan subjek penelitian tiga anak, yakni Ve (usia 2 tahun 6 bulan), Cc (Usia 2 tahun 10 bulan), dan Ad (Usia 2 tahun 10 bulan). Subjek dipilih dengan kriteria: (1) minimal sudah bisa mengikuti instruksi dan sudah bisa diajak komunikasi; (2) berada pada rentang usia 
2-3 tahun; (3) orang tua menunjukkan penerimaan yang hangat pada penelitian ini; dan (4) mudah dijangkau oleh peneliti.

Data dikumpulkan menggunakan observasi, wawancara dan beberapa rangkaian stimulus untuk mendukung munculnya respon pencapaian perkembangan yang hendak diukur berdasarkan tingkat pencapaian perkembangan anak dalam Peraturan Menteri Pendidikan dan Kebudayaan Republik Indonesia Nomor 137 Tahun 2014 Tentang Standar Nasional Pendidikan Anak Usia Dini. Aspek yang diukur mulai aspek nilai agama-moral, fisik-motorik, kognitif, bahasa, sosialemosional, sampai pada aspek seni. Data yang sudah terkumpul dianalisis menggunakan analisis deskriptif. Uji kredibilitas data terhadap hasil penelitian dilakukan dengan perpanjangan waktu pengamatan dan diskusi dengan teman sejawat.

\section{HASIL DAN PEMBAHASAN \\ Aspek Nilai Agama dan Moral}

Tingkat pencapaian perkembangan anak dalam aspek perkembangan nilai agama dan moral dapat dilihat dari dua indikator: Pertama, mulai meniru gerakan berdoa/sembahyang sesuai dengan agamanya. Kedua, mulai memahami kapan mengucapkan salam, terima kasih, maaf, dsb.

Berdasarkan hasil penelitian dari tiga subjek maka didapatkan gambaran ketiga subjek sudah mampu meniru gerakan berdoa/sembahyang. Hal ini terlihat ketika Ve mengikuti ibunya berdoa terlebih dahulu sebelum makan. Cc mempratikkan beberapa gerakan dalam shalat begitu pula dengan berdoa. Ad juga sudah mampu menunjukkan cara berdoa dan memahami kapan mengucapkan salam, terima kasih, maaf, dsb., ketiga subjek sudah memahaminya. Hal ini terlihat ketika ketiga subjek diberikan stimulasi dengan memberikan cemilan, mereka mengambilnya dan tidak lupa mengucapkan terima kasih.

Ketiga subjek sudah mampu melakukan semua indikator dengan baik. Hal ini dikarenakan, pola asuh yang diberikan orangtua kepada anak sudah baik yaitu dengan memberikan bimbingan dalam beribadah dan berkata baik, serta menunjukkan perilaku terpuji lainnya yang patut diteladani oleh anak. Menurut Yusuf (2016), keluarga merupakan "Training Centre" bagi pemahaman nilai-nilai, pengembangan fitrah atau jiwa beragama. Dalam mengembangkan fitrah beragama anak dalam lingkungan keluarga, orang tua hendaknya membimbing, mengajarkan, atau melatihkan ajaran agama terhadap anak, seperti: syahadat; shalat (bacaan dan gerakannya); berwudlu; doa-doa, bacaan Al-Qur'an; lafaz zikir dan akhlak terpuji.

Perkembangan moral anak dapat berlangsung melalui beberapa cara menurut Yusuf (2016) salah satunya yaitu Pendidikan Langsung. Pendidikan langsung yaitu melalui penanaman pengertian tentang tingkah laku yang benar dan salah, atau baik dan buruk oleh orangtua, guru atau orang dewasa lainnya. Di samping itu, yang paling 
penting dalam pendidikan moral, adalah keteladanan dari orangtua, guru, atau orang dewasa lainnya dalam melakukan nilai-nilai moral.

\section{Aspek Perkembangan Fisik Motorik}

Perkembangan fisik dan motorik anak saling terkait dan saling menunjang satu sama lain. Aspek perkembangan motorik terbagi atas dua yaitu aspek perkembangan motorik kasar dan motorik halus. Tingkat pencapaian perkembangan anak dalam aspek perkembangan motorik kasar dapat dilihat dari 5 indikator yaitu: Pertama, berjalan sambil berjinjit. Kedua, melompat ke depan dan ke belakang dengan dua kaki. Ketiga, melempar dan menangkap bola. Keempat, menari mengikuti irama. Kelima, naik turun tangga atau tempat yang lebih tinggi/rendah dengan berpegangan. Sedangkan tingkat pencapaian perkembangan anak dalam aspek perkembangan motorik halus dapat dilihat dari 4 indikator yaitu: Pertama, meremas kertas atau kain dengan menggerakkan lima jari. Kedua, melipat kain/kertas meskipun belum rapi/lurus. Ketiga, menggunting kertas tanpa pola. Keempat, koordinasi jari tangan cukup baik untuk memegang benda pipih seperti sikat gigi, sendok.

Berdasarkan hasil penelitian dari tiga subjek, didapatkan gambaran perkembangan motorik kasar sebagai berikut yaitu Cc dan Ad sudah mampu melakukan semua indikator perkembangan dengan baik sedangkan Ve masih ada indikator yang belum mampu dilakukan yaitu pada indikator melompat ke depan dan ke belakang dengan dua kaki serta melompat dan menangkap bola. Sedangkan untuk motorik halus, berdasarkan hasil penelitian dari tiga subjek didapatkan gambaran ketiga subjek sudah mampu melakukan semua indikator perkembangan dari motorik halus.

Ada tujuh indikator yang menjadi penunjang perkembangan motorik anak terkait kesehatan dan perilaku keselamatan yaitu: Pertama, berat badan sesuai tingkat usia. Kedua, tinggi badan sesuai tingkat usia. Ketiga, berat badan sesuai dengan standar tinggi badan. Keempat, lingkar kepala sesuai tingkat usia. Kelima, mencuci, membilas, dan mengelap ketika cuci tangan tanpa bantuan. Keenam, memberitahu orang dewasa bila sakit. Ketujuh, mencuci atau mengganti alat makan bila jatuh.

Berdasarkan hasil penelitian dari tiga subjek didapatkan gambaran sebagai berikut yaitu hanya Ad yang memenuhi dan mampu melakukan semua indikator terkait kesehatan dan perilaku keselamatan sedangkan Ve masih ada dua indikator yang belum memenuhi yakni belum memiliki tinggi badan sesuai dengan tingkat usia. Sementara Cc masih ada satu indikator yang belum mampu dilakukan yakni Cc tidak mengganti alat makannya bila jatuh, anak tersebut hanya langsung mengambilnya lalu menggunakannya kembali. Akan tetapi, jika orangtuanya melihat alat makan anak jatuh, ibunya segera menggantikan alat makannya. 
Hasil penelitian dari aspek perkembangan fisik motorik menunjukkan bahwa perkembangan ketiga subjek sudah berkembang dengan baik meskipun masih ada beberapa yang belum mampu dilakukannya dalam aspek perkembangan motorik kasarnya. Keberhasilan perkembangan dari ketiga subjek tidak terlepas dari peran orangtua dalam memberikan stimulasi yang tepat dan memberikan kebebasan kepada anak untuk melakukan aktivitas yang diinginkan. Selain itu, pemberian gizi juga berpengaruh terhadap pertumbuhan dan perkembangan motorik anak.

Sebagaimana pendapat Indrijati (2016) bahwa stimulasi sangat diperlukan agar perkembangan fisik dan motorik anak dapat lebih optimal. Stimulasi tersebut dapat berupa sikap orangtua yang lebih terbuka, kegiatan yang mengasah keterampilan fisik motorik, fasilitas permainan yang memungkinkan gerak bebas anak, sehingga dapat memantapkan keterampilan motorik baik halus maupun kasar. Ada beberapa sikap yang bisa dikembangkan orangtua untuk menstimulasi perkembangan motorik anak, yaitu: pertama, memberikan kesempatan belajar anak untuk mempelajari kemampuan motoriknya, agar anak tersebut tak mengalami kelambatan perkembangan; kedua, memberikan kesempatan mencoba seluasluasnya agar anak tersebut bisa menguasai kemampuan motoriknya; ketiga, memberikan contoh yang baik, karena mempelajari dan mengembangkan kemampuan motoriknya lewat cara meniru, anak perlu mendapat contoh yang tepat dan baik; keempat, memberikan bimbingan kerana meniru tanpa bimbingan tidak akan mendapatkan hasil optimal. Ini penting agar anak tersebut mengenali kesalahannya.

Selain berbagai kegiatan stimulasi, hal lain yang memengaruhi perkembangan motorik anak yaitu gizi anak. Menurut Desmita (2012) makanan merupakan salah satu faktor yang mempengaruhi perkembangan individu. Hal ini terutama pada tahun-tahun pertama dari kehidupan anak, makanan merupakan faktor yang sangat penting bagi pertumbuhan yang normal dari setiap individu. Oleh sebab itu, dalam rangka perkembangan dan pertumbuhan anak menjadi sehat dan kuat, perlu memperhatikan makanan, tidak saja dari segi kuantitas (jumlah) makanan yang dimakan, melainkan juga dari segi kualitas (mutu) makanan itu sendiri. Makanan yang banyak hanya akan mengenyangkan perut tetapi gizi yang cukup akan dapat menjamin pertumbuhan yang sempurna. Banyak penelitian (Indrijati, 2016) yang menerangkan tentang pengaruh gizi terhadap kecerdasan serta perkembangan motorik kasar. Keadaan kurang energi dan protein, anak menjadi tidak aktif, apatis, pasif, dan tidak mampu berkonsentrasi. Akibatnya, anak dalam melakukan kegiatan eksplorasi lingkungan fisik di sekitarnya tidak akan optimal, karena ketahanan tubuhnya yang kurang memadai. Anak tersebut hanya mampu sebentar saja melakukam suatu aktivitas dibandingkan dengan anak yang gizinya baik, yang mampu melakukannya dalam waktu yang lebih lama.

Stimulasi yang dapat diberikan kepada anak untuk mengembangkan berbagai aspek perkembangan anak dapat pula melalui kegiatan bermain. Menurut Utami 
Munandar dalam Fadlillah (2017) menyebutkan bahwa bermain merupakan suatu aktivitas yang membantu anak mencapai perkembangan yang utuh, baik fisik, intelektual, sosial, moral, dan emosional. Bermain dijadikan sarana untuk mencapai seluruh perkembangan anak usia dini, mulai dari fisik-motorik sampai sosialemosionalnya.

\section{Aspek Perkembangan Kognitif}

Tingkat pencapaian perkembangan anak dalam aspek perkembangan kognitif dapat dilihat dari 5 indikator untuk belajar dan pemecahan masalah yaitu: Pertama, melihat dan menyentuh benda yang ditunjukkan oleh orang lain. Kedua, meniru cara pemecahan orang dewasa atau teman. Ketiga, konsentrasi dalam mengerjakan sesuatu tanpa bantuan orang tua. Keempat, mengeksplorasi sebab akibat. Kelima, mengikuti kebiasaan sehari-hari (mandi, makan, pergi ke sekolah). Sedangkan untuk berpikir logis, terdapat 6 indikator yaitu: Pertama, menyebut bagian-bagian suatu gambar seperti gambar wajah orang, mobil binatang, dsb. Kedua, mengenal bagianbagian tubuh (lima bagian). Ketiga, memahami konsep ukuran (besar-kecil, panjangpendek). Keempat, mengenal tiga macam bentuk. Kelima, mulai mengenal pola. Keenam, memahami simbol angka dan maknanya.

Untuk belajar dan pemecahan masalah, hanya Ve dan Cc yang sudah mampu melakukan semua indikator perkembangan yakni melihat dan menyentuh benda yang ditunjukkan oleh orang lain, meniru cara pemecahan orang dewasa atau teman, konsentrasi dalam mengerjakan sesuatu tanpa bantuan orang tua, mengeksplorasi sebab akibat dan mengikuti kebiasaan sehari-hari. Sedangkan Ad masih ada satu indikator yang belum mampu dilakukan yakni belum mampu mengeksplorasi sebab dan akibat.

Untuk berpikir logis, masih banyak indikator yang belum mampu dilakukan oleh ketiga subjek. Ketiga subjek sudah mampu menyebutkan bagian-bagian suatu gambar, dan sudah mengenal bagian-bagian tubuh. Namun hanya Cc dan Ad yang memahami konsep ukuran. Sedangkan Ve belum mampu memahami konsep ukuran. Untuk indikator mengenal tiga macam bentuk, ketiga subjek belum ada yang mampu. Hal ini terlihat ketika anak diminta untuk menyebutkan gambar yang ditunjukkan, anak belum mampu menyebutkan gambar tersebut. Untuk indikator pengenalan pola, hanya Ad yang mampu mengenal pola. Hal ini terlihat ketika diminta untuk mengelompokkan benda warna kuning dengan warna kuning, dia sudah mampu. Sedangkan Ve dan Cc belum mengenal pola, masih terbalik-balik antara pola yang satu dengan pola yang lain ketika ditunjukkan. Untuk indikator memahami simbol dan angka, hanya Ve dan Cc yang sudah memahami simbol angka dan maknanya meskipun hanya angka 1-5 saja. Sedangkan Ad belum memahami simbol angka dan maknanya. Hal ini terlihat ketika Ad ditunjukkan simbol angka, Ad hanya menggeleng-gelengkan kepala. 
Hasil penelitian standar pencapaian perkembangan kognitif dari ketiga subjek menunjukkan masih banyak indikator yang belum tercapai terutama dalam mengenal konsep ukuran, macam-macam bentuk dan simbol angka dan maknanya. Berdasarkan wawancara ke orangtua, menunjukkan kurangnya kreativitas serta pemahaman orangtua dalam membuat media-media dan alat permainan edukatif yang dapat mendukung pembelajaran sehingga anak merasa tidak tertarik untuk belajar. Mereka hanya memberikan stimulasi kognitif seadanya saja.

Menurut Harlock dalam Putro (2016), dalam bermain banyak sekali variasi kegiatan yang dilakukan oleh anak, hal ini dipengaruhi oleh beberapa faktor, salah satunya yaitu: alat permainan. Alat permainan akan menentukan jenis bermainnya sehingga perlu disediakan berbagai variasi alat permainan sehingga memungkinkan anak bermain dengan berbagai cara. Hal ini akan berdampak positif pada aspek perkembangannya. Alat permainan berfungsi sebagai dorongan atau tantangan bagi anak. Dalam kegiatan bermain, anak bebas untuk berimajinasi, bereksplorasi, dan menciptakan sesuatu. Untuk mencapai manfaat positif dari bermain maka dibutuhkan alat permainan yang tepat untuk anak, alat permainan yang sesuai dan mendukung perkembangan semua dimensi anak.

Menurut Beaty (dalam Efrina, 2018) mengembangkan kemampuan kognitif anak dapat dilakukan melalui kegiatan bermain dengan tiga cara, yaitu sebagai berikut: pertama, memanipulasi (meniru) apa yang terjadi dan dilakukan oleh orang dewasa atau objek yang ada disekitar anak; kedua, mastery yaitu menguasai suatu aktifitas dengan mengulangi suatu kegiatan yang tentunya menjadi kesenangan dan memberikan kebermaknaan pada diri anak; ketiga, meaning yaitu memberikan kebermaknaan pada diri anak sehingga menumbuhkan motivasi bagi anak dalam melakukannya.

Vygotsky (dalam Rohani, 2016) menyatakan bahwa bermain adalah suatu setting yang sangat bagus bagi perkembangan kognitif. Hal yang sama diungkapkan oleh Garvey (dalam Rohani, 2016) bahwa bermain memiliki nilai positif bagi anak yang motivasinya lebih bersifat intrinsic, dalam bermain juga harus bersifat spontan dan sukarela, tidak ada unsur keterpaksaan dan bebas dipilih oleh anak serta melibatkan peran aktif keikutsertaan anak. Hal yang terpenting menurut Garvery bahwa bermain memiliki hubungan dengan kemampuan kreativitas, kemampuan memecahkan masalah, belajar bahasa, perkembangan sosial, dan lain sebagainya. Plato (dalam Rohani, 2016) mencatat bahwa anak akan lebih mudah memahami aritmatika ketika diajarkan melalui bermain. Anak lebih mampu menerapkan aritmatika dengan bermain dibandingkan dengan tanpa bermain.

\section{Aspek Perkembangan Bahasa}

Tingkat pencapaian perkembangan aspek bahasa dalam hal memahami bahasa terdapat 4 indikator yaitu: pertama, memainkan kata atau suara yang didengar dan diucapkan berulang-ulang; kedua, hafal bebrapa lagu anak sederhana; 
ketiga, memahami cerita atau dongeng sederhana; dan keempat, memahami perintah sederhana seperti letakkan mainan di atas meja, ambil mainan dari dalam kotak.

Berdasarkan hasil penelitian dari tiga subjek maka didapatkan gambaran mengenai perkembangan bahasa anak yang berbeda-beda dalam hal memainkan kata atau suara yang didengar dan diucapkan berulang-ulang. Hanya dua subjek yaitu Cc dan Ad saja yang mampu memainkan kata atau suara yang didengar dan diucapkan berulang-ulang. Sedangkan Ve belum mampu untuk memainkan kata atau suara yang didengar dan diucapkan berulang-ulang. Hal ini dilihat ketika mendengarkan kata atau suara, subjek akan mengikutinya beberapa kali, tetapi jika untuk diucapkan berulang-ulang, tidak ada kata yang spesifik yanganak tersebut katakan dan berulang-ulang, kata-katanya selalu berubah. Adapun untuk indikator hafal beberapa lagu anak sederhana juga hanya terdapat dua subjek yang mampu untuk menghafal beberapa lagu anak sederhana yaitu Ve dan Cc saja. Sedangkan subjek Ad hanya mampu menghapal satu lagu saja yaitu lagu cicak di dinding. Untuk indikator memahami cerita atau dongeng sederhana, Ve dan Cc sudah mampu untuk mendengar dengan baik dongeng yang diceritakan namun untuk memahami anak belum terlalu paham. Sedangkan untuk Ad belum memahami cerita atau dongeng sederhana. Berdasarkan hasil wawancara dengan orangtua Ad, ketika Ad dibacakan sebuah dongeng atau cerita Ad belum mampu memahami dongeng atau cerita tersebut. Ad hanya sekedar mendengar saja. Sementara untuk indikator memahami perintah sederhana seperti letakkan mainan di atas meja, ambil mainan dari dalam kotak, ketiga subjek sudah mampu untuk memahami perintah sederhana seperti meletakkan gelas di atas meja, mengambil gelas kemudian merapikan mainannya setelah bermain.

Kemudian untuk perkembangan bahasa anak dalam mengungkapkan bahasa terdiri atas dua indikator yaitu: pertama, menggunakan kata tanya dengan tepat (apa, siapa, bagaimana, mengapa, dimana); dan kedua, menggunakan 3 atau 4 kata untuk memenuhi kebutuhannya (misal, mau minum air putih).

Berdasarkan hasil penelitian didapatkan bahwa ketiga subjek sudah mampu untuk menggunakan kata tanya dengan tepat, seperti "siapa itu ibu?", "dimana bonekaku yang besar itu?", "siapa nama kakak?". Selain itu ketiga anak juga sudah menggunakan 3 atau 4 kata untuk memenuhi kebutuhannya. Hal ini dapat dilihat ketika Ve ingin mandi anak tersebut akan mengatakan pada ibunya "ibu mauka mandi", sementara untuk Cc dapat dilihat ketika hendak makan maka Cc akan mengatakan bahwa anak tersebut ingin makan serta menyebutkan apa yang anak tersebut ingin makan seperti "mama saya mau makan nasi sama telur". Dan untuk Ad dapat dilihat ketika Ad ingin minum susu anak tersebut akan mengatakan "mama saya mau minum susu".

Kemampuan bahasa yang dimiliki oleh ketiga subjek berbeda-beda. Faktor yang mempengaruhi sesuai dengan pendapat Susanto (2017) bahwa secara 
naluriah, anak memiliki potensi untuk berkomunikasi dengan lingkungannya namun dipengaruhi oleh faktor: (1) pengaruh biologis; (2) perkembangan intelektual, dan (3) pengaruh lingkungan keluarga dan lingkungan sosial anak. Dari penelitian yang dilakukan, Ve mengalami keterlambatan karena memang dia paling muda di antara subjek yang lain. Artinya bisa jadi perkembangan intelektualnya belum seperti Cc dan Ad karena semakin tinggi usia, maka berkorelasi dengan perkembangan intelektualnya. Semakin berkembang maka semakin mampu memahami lingkungan maka bahasa mulai berkembang dari tingkat sederhana ke tingkat kompleks. Keterlambatan bahasa Ve dibanding subjek lainnya karena Ve belum sekolah sehingga sosialisasinya terbatas hanya kepada orang-orang disekitar rumahnya saja.

Santrock (2008) mengemukakan strategi yang dapat diterapkan orang terdekat untuk menstimulasi perkembangan bahasa anak, yakni: (1) Motherese, dengan berbicara dengan intens menggunakan bahasa sederhana; (2) Recasting, dengan mengucapkan makna suatau kalimat yang sama dengan cara berbeda, misalnya dengan bentuk pertanyaan; (3) Echoling, dengan mengulangi apa yang anak katakana, khususnya kata yang tidak sempurna; (4) Expanding, dengan menyatakan ulang apa yang telah anak katakan; dan (5) Labeling, dengan mengidentifikasi nama-nama benda.

\section{Aspek Perkembangan Sosial Emosional}

Aspek perkembangan sosial emosional terdiri atas kesadaran diri, tanggung jawab diri dan orang lain serta perilaku prososial. Untuk hal kesadaran diri terdiri atas 4 indikator yaitu: pertama, memberi salam setiap mau pergi; kedua, memberi reaksi percaya pada orang dewasa; ketiga, menyatakan perasaan terhadap anak lain; dan keempat, berbagi peran dalam suatu permainan (misal: menjadi dokter, perawat, pasien). Untuk hal tanggung jawab diri dan orang lain terdiri atas 3 indikator yaitu: pertama, mulai bisa mengungkapkan ketika ingin buang air kecil dan buang air besar; kedua, mulai memahami hak orang lain (harus antri, menunggu giliran); dan ketiga, mulai menunjukkan sikap berbagi, membantu, bekerja bersama. Sementara untuk perilaku prososial terdiri atas 4 indikator pula yaitu: pertama, bermain secara kooperatif dalam kelompok; kedua, peduli dengan orang lain (tersenyum, menanggapi bicara); ketiga, membagi pengalaman yang benar dan salah pada orang lain; keempat, bermain bersama berdasarkan aturan tertentu.

Berdasarkan hasil observasi terhadap tiga subjek didapatkan hasil yang berbeda-beda mengenai kesadaran diri pada setiap anak. Ve dan Ad sudah mampu memberi salam setiap mau pergi, sementara Cc juga sudah mampu memberi salam dengan cukup baik namun untuk mengaplikasikan setiap ingin pergi masih kadangkadang dan hanya diaplikasikan ketika diingatkan oleh orangtua. Selain itu, ketiga subjek sudah mampu memberi reaksi percaya terhadap orang dewasa yang dibuktikan ketika Ve melihat tantenya datang Ve langsung memeluk tantenya. Begitu pula dengan Cc dan Ad yang ditunjukkan ketika mereka merasa takut sendirian 
mereka akan memanggil orangtua untuk menemaninya. Cc dan Ad juga sudah mampu menyatakan perasaan terhadap anak lain. Sedangkan Ve belum mampu untuk menyatakan perasaan terhadap teman lain. Menurut orangtuanya Ve memang hanya memiliki teman bergaul yang terbatas. Ketiga subjek juga sudah mampu untuk berbagi peran dalam suatu permainan yang nampak saat penelitian berlangsung saat permainan motor-motoran, ibu-ibuan melalui permainan boneka dan permainan make up boneka.

Untuk indikator dalam hal tanggung jawab diri dan orang lain, ketiga subjek sudah mampu mengungkapkan ketika ingin buang air kecil dan besar. Selain itu dalam memahami hak orang lain (harus antri, menunggu giliran), hanya Ve yang sudah mampu untuk memahami menunggu giliran. Sementara Cc dan Ad belum mampu memahami dengan baik hak-hak orang lain seperti antri namun sudah mulai menunjukkan sikap paham seperti pada saat bermain anak tersebut akan menunggu dengan tenang apabila temannya sedang memakai mainan yang anak tersebut ingin mainkan. Ketiga subjek juga sudah mampu menunjukkan sikap berbagi, membantu. Hanya saja tinggal Ad yang belum mampu dalam hal bekerja sama.

Adapun hasil penelitian untuk indikator dalam hal perilaku prososial, ketiga subjek belum mampu bermain secara kooperatif dalam kelompok dikarenakan Ve sangat jarang bermain di luar rumah, Cc lebih suka bermain sendiri dibanding dengan bermain dengan teman dan Ad hanya bermain sesukanya. Jika sudah merasa bosan, maka Ad akan berhenti bermain. Selain itu, ketiga subjek sudah mampu untuk peduli dengan orang lain, seperti tersenyum atau menyapa lawan bicaranya. Ketiga subjek masih sulit dalam berbagi pengalaman benar dan salah. Mereka hanya tahu beberapa perbuatan benar salah namun belum mampu membagi pengalamannya. Ve dan Cc sudah mampu untuk bermain bersama berdasarkan aturan tertentu. Sedangkan Ad belum mampu untuk bermain bersama berdasarkan aturan tertentu karena hanya bermain sesuai dengan keinginannya sendiri.

Perkembangan sosial emosional anak dipengaruhi beberapa faktor yakni: (1) Pengaruh keadaan individu sendiri, seperti usia, keadaan fisik, inteligensi, peran seks, kematangan belajar, konflik-konflik dalam proses perkembangan, pengalaman sosial anak; (2) Lingkungan, termasuk keluarga (status ekonomi keluarga, keutuhan keluarga, sikap dan kebiasaan orang tua), lingkungan tempat tinggal dan lingkungan sekolah (Setiawan, 1995; Hurlock dalam Susanto, 2011; Tirtayani, dkk, 2014; Patmonodewo dalam Susanto, 2011; Mayar, 2013; Tirtayani, dkk, 2014)

Menurut Tirtayani, dkk (2014) karena usia anak usia dini merupakan usia dimana belum stabilnya perkembangan sosial emosi mereka, maka orang tua atau orang dewasa disekitar anak dapat menciptakan kondisi yang dapat menjamin perkembangan sosial emosional anak dengan cara menyediakan kondisi yang dapat menjamin terkendalinya ekspresi emosi dari setiap anak sehingga anak terlindungi, 
lebih stabil, dan seimbang. Selain itu, orang tua atau pendidik bisa memfasilitasi dan menyiapkan kondisi yang dapat membantu anak melakukan interaksi sosial serta meningkatkan keterampilan anak dalam bersosialisasi.

\section{Aspek Perkembangan Seni}

Perkembangan seni anak terdiri dari indikator (1) Anak mampu membedakan antara bunyi; (2) Tertarik dengan kegiatan musik, gerakan orang, hewan maupun tumbuhan (menyanyi sampai tuntas dengan irama yang benar (nyanyian pendek atau empat bait), menyanyikan lebih dari tiga lagu dengan irama yang benar sampai tuntas (nyanyian pendek atau empat bait), bersama teman-teman menyanyikan lagu, bernyanyi mengikuti irama dengan bertepuk tangan atau menghentakkan kaki, meniru gerakan berbagai binatang, paham bila orang terdekatnya (ibu) menegur, mencontoh gerakan orang lain, dan bertepuk tangan sesuai irama); dan (3) tertarik dengan kegiatan atau karya seni (menggambar benda-benda lebih spesifik, mengamati dan membedakan benda-benda disekitarnya yang ada di dalam rumah)

Berdasarkan hasil penelitian dari indikator memperhatikan dan mengenali suara yang bernyanyi atau berbicara. Didapatkan hasil bahwa ketiga subjek sudah mampu untuk memperhatikan dan mengenali suara yang bernyanyi atau berbicara. Untuk indikator tertarik dengan kegiatan musik, gerakan orang, hewan maupun tumbuhan, Ve dalam menyanyi hanya beberapa kata dan terkadang iramanya tidak sesuai. Meski begitu, Ve sudah mampu menyanyi bersama orangtuanya. Sementara Cc sudah mampu menyanyikan sebuah lagu anak sampai tuntas dengan irama yang benar dan sudah bisa menghafalnya, seperti lagu cicak di dinding, kasih ibu, dan masuk sekolah. Dia juga sudah mampu menyanyi bersama teman-temannya. Lain halnya dengan Ad yang belum mampu menyanyi sampai tuntas dengan irama yang benar, anak tersebut hanya mampu menyanyikan beberapa bait dari lagu, anak tersebut hanya mengahapal satu lagu saja yaitu cicak di dinding. Dia juga belum mampu menyayi bersama temannya. Ketiga subjek masih belum mampu untuk bernyanyi mengikuti irama sambil bertepuk tangan atau menghentakkan kaki. Namun ketiga subjek sudah mampu untuk meniru gerakan binatang, sudah mampu untuk memahami jika ditegur oleh orang dewasa disekitarnya, dan sudah mampu untuk mencontoh gerakan orang lain.

Untuk hasil penelitian dari indikator-indikator tentang tertarik dengan kegiatan atau karya seni, ketiga subjek masih belum mampu menggambar benda dengan spesifik. Ketiga subjek hanya mampu membuat coretan-coretan yang masih kurang jelas. Namun ketiga subjek sudah mampu mengamati dan membedakan benda yang ada disekitarnya meskipun memang masih ada beberapa benda yang belum diketahuinya yakni benda yang tidak pernah digunakan.

Secara keseluruhan, kemampuan seni ketiga subjek menggambarkan perkembangan yang sudah lumayan bagus karena hampir semua indikator tingkat pencapaian perkembangan telah dipenuhi oleh ketiga anak. Indikator yang paling 
menonjol belum terpenuhi adalah bernyanyi mengikuti irama dengan bertepuk tangan atau menghentakkan kaki dan menggambar benda-benda lebih spesifik. Berdasarkan informasi dari orang tua mereka didapatkan informasi bahwa memang anak-anak mereka tidak pernah dipandu menyanyi sambil menghentakkan kaki karena dianggap tabu goyang-goyang. Selain itu mereka dilarang mencoret sana sini apalagi di dinding dan lantai sehingga ketiga subjek belum terampil dalam mencoret.

Huliyah, M (2016) mengemukakan perkembangan seni pada anak usia dini dapat didukung dengan penerapan pembelajaran seni dan kreativitas pada anak usia dini yang menekankan pada 3 aspek yaitu: pertama: aspek eksplorasi, pengembangan kemampuan bereksplorasi dapat dilakukan dengan memberikan kesempatan kepada anak untuk melakukan beberapa hal-hal seperti: melihat lingkungan dan bagian-bagiannya; menggambar objek tertentu berdasarkan observasi yang dilakukannya; dan mengatur tinggi/rendah, cepat/lambat, keras/pelan pada vocal pembicaraan atau lagu. Kedua: ekspresi, pengembangan kemampuan berekspresi dapat dilakukan dengan memberikan kesempatan kepada anak untuk melakukan hal-hal seperti mengekspresikan pikiran dan perasaan melalui kegiatan menggambar; bernyanyi lagu sederhana; dan mengeksplorasi jenis gerak tubuh dan ekspresi dengan drama. Dan ketiga: apresiasi, kemampuan apresiasi pada anak usia dini harus dikembangkan dengan tujuan agar anak dapat menilai dan menghargai pengalaman berkesenian dan karya seni.

\section{SIMPULAN}

Kesimpulan penelitian ini menggambarkan deskripsi tingkat pencapaian perkembangan ketiga subjek penelitian mulai dari aspek nilai agama-moral, fisikmotorik, kognitif, bahasa, sosial-emosional, sampai pada aspek seni. Perkembangan nilai agama dan moral menunjukkan bahwa ketiga subjek sudah mampu melakukan semua indikator dengan baik. Hal ini disebabkan karena pola asuh yang diberikan orangtua sudah baik dengan memberikan bimbingan dan contoh yang baik kepada anak. Dalam aspek perkembangan fisik-motorik menunjukkan bahwa dua dari tiga subjek sudah mampu melakukan semua indikator perkembangan motorik kasar dengan baik sedangkan untuk motorik halus, ketiga subjek sudah mampu melakukan semua indikator perkembangan. Keberhasilan perkembangan dari ketiga subjek tidak terlepas dari peran orangtua dalam memberikan stimulasi yang tepat dan memberikan kebebasan untuk melakukan aktivitas yang diinginkan. Selain itu, pemberian gizi juga mempengaruhi pertumbuhan dan perkembangan fisikmotorik anak. Perkembangan kognitif menunjukkan bahwa masih banyak indikator yang belum tercapai terutama dalam berpikir logis. Oleh karena ini, orangtua harus kreatif dalam membuat media-media dan alat permainan edukatif yang dapat mendukung pembelajaran sehingga anak tertarik untuk belajar. Dalam aspek perkembangan bahasa, hanya dua subjek yang mampu melakukannya dalam setiap indikator. Untuk indikator menggunakan kata tanya dengan tepat dan menggunakan 
3 atau 4 kata untuk memenuhi kebutuhannya, ketiga subjek sudah mampu melakukannya. Dalam aspek perkembangan sosial-emosional, ketiga subjek sudah berkembang dengan baik. Akan tetapi masih ada beberapa yang belum mampu dilakukan, hal ini disebabkan karena tingkah laku anak yang masih mementingkan diri sendiri atau bersikap egosentris. Oleh karena itu, orangtua harus lebih sering mengajak anak bermain di luar yang melibatkan beberapa anak sehingga sikap egosentris anak bisa berkurang. Dalam aspek perkembangan seni menggambarkan perkembangan yang sudah lumayan bagus karena hampir semua indikator tingkat pencapaian perkembangan telah dipenuhi oleh ketiga anak, hanya saja masih ada yang belum mampu dilakukan terutama dalam hal bernyanyi mengikuti irama sambil bertepuk tangan dan menghentakkan kaki serta menggambar benda dengan spesifik.

\section{DAFTAR PUSTAKA}

Danim, Sudarwan. (2010). Perkembangan Peserta Didik. Bandung: Alfabeta.

Desmita. (2012). Psikologi Perkembangan Peserta Didik. Bandung: PT Remaja Rosdakarya.

Fadlillah, M. (2017). Bermain dan Permainan. Jakarta: Kencana.

Hidayat, O.S. (2000). Metode pengembangan moral dan nilai-nilai agama. Jakarta: Universitas Terbuka.

Huliyah, M. (2016). Pengembangan Daya Seni Pada Anak Usia Dini. Jurnal Pendidikan Guru Rudhatul Athfal, Vol. 1 No.2 Tahun 2016.

Hurlock, E.B. (2002). Psikologi Perkembangan; Suatu Pendekatan Sepanjang Rentang Kehidupan. Jakarta: Erlangga.

Indrijati, Herdina. (2016). Psikologi Perkembangan \& Pendidikan Anak Usia Dini Sebuah Bunga Rampai. Jakarta: Kencana.

Mayar, F. (2013). Perkembangan Sosial Anak Usia Dini Sebagai Bibit Untuk Masa Depan Bangsa. Jurnal Al-Ta'lim, Jilid 1 Nomor 6 November 2013.

Peraturan Menteri Pendidikan dan Kebudayaan Republik Indonesia Nomor 137 Tahun 2014 Tentang Standar Nasional Pendidikan Anak Usia Dini

Putro, K.Z. (2016). Mengembangkan Kreativitas Anak Melalui Bermain. Jurnal Aplikasi IImu-ilmu Agama, Vol 16 No. 1 Tahun 2016.

Rohani. (2016). Mengoptimalkan Perkembangan Kognitif Anak Melalui Kegiatan Bermain. Jurnal Raudah, Vol. 4 No.2 Tahun 2016.

Santrock. J. (2008). Psikologi Pendidikan. Jakarta: Kencana 
Setiawan. (1995). Kreativitas dan Keberbakatan. Jakarta: Indeks

Sit, Masganti. 2017. Psikologi Perkembangan Anak Usia Dini. Depok: Kencana.

Susanto, A. (2014). Perkembangan Anak Usia Dini: Pengantar Dalam Berbagai Aspeknya. Jakarta: Kencana

Tirtayani, L.A., Asril., N.M., \& Wirya, I. (2014). Perkembangan Sosial Emosional pada Anak Usia Dini. Yogyakarta: Graha IImu.

Yusuf, Syamsu. (2016). Psikologi Perkambangan Anak dan Remaja. Bandung: PT Remaja Rosdakarya.

24 NANAEKE - Indonesian Journal of Early Childhood Education, Vol. 2, No. 1, Juni 2019 